\title{
Painful legs and moving toes syndrome
}

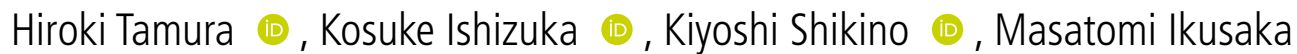

General Medicine, Chiba University Hospital, Chiba, Japan

\section{Correspondence to}

Mr Kosuke Ishizuka;

e103007c@yokohama-cu.ac.jp

Accepted 26 December 2020

\section{DESCRIPTION}

A 74-year-old woman presented with a 5-year history of persistent dysaesthesia accompanied by pain in her right first to third toes. She denied urging to move her toes. The pain improved with standing, walking and plantar compression. The patient had been taking amlodipine for hypertension and pramipexole, carbamazepine and pregabalin for the pain, none of which were effective. A physical examination revealed that the movements of the second and third toes were primarily slow lateral movements (abduction and adduction) irregularly similar to $1 \mathrm{~Hz}$ myoclonus (figure 1 , video 1 ). There were no other neurological findings. In addition, nerve conduction study, cranial and lumbar MRI and DaTSCAN imaging findings were not significant. The patient was diagnosed with painful legs and moving toes (PLMT) syndrome, and treatment with clonazepam provided relief.

PLMT syndrome refers to an uncommon movement disorder characterised by limb pain accompanied by repetitive nonrhythmic digit movements. ${ }^{1}$ The movements of the toes may be flexion, extension, abduction, adduction, dystonic, myoclonic or sometimes rhythmic. ${ }^{2}$ In addition, it is characteristic that these movements are observed with slow frequency of $1-2 \mathrm{~Hz}^{3}$ Pain exacerbating or improving features are often identified (58\%), including various body positions (sitting, walking/ weight bearing or bending), diurnal variations (night vs day), cold temperature and external pressure (blankets or shoes). ${ }^{1}$ PLMT syndrome is often attributed to peripheral neuropathy (28\%), trauma

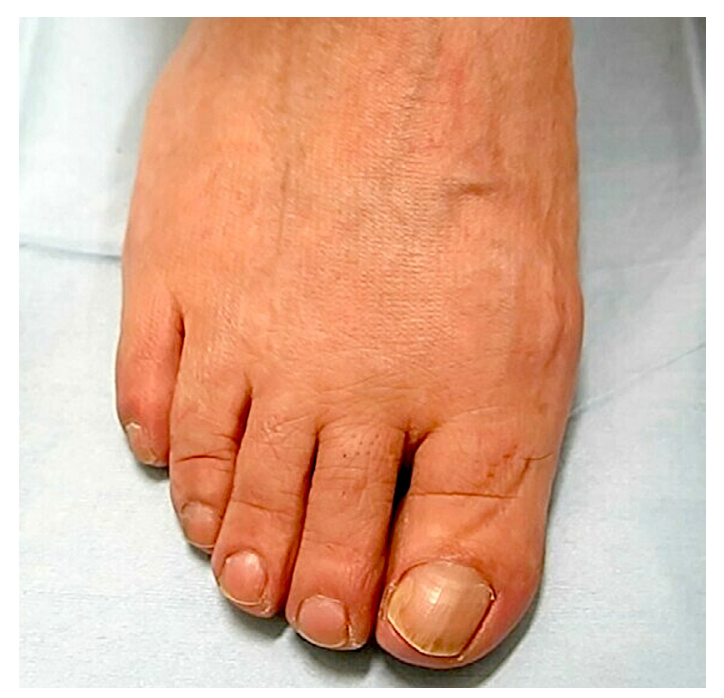

Figure 1 The movements of the second and third toes were primarily slow lateral movements (abduction and adduction) irregularly similar to $1 \mathrm{~Hz}$ myoclonus.

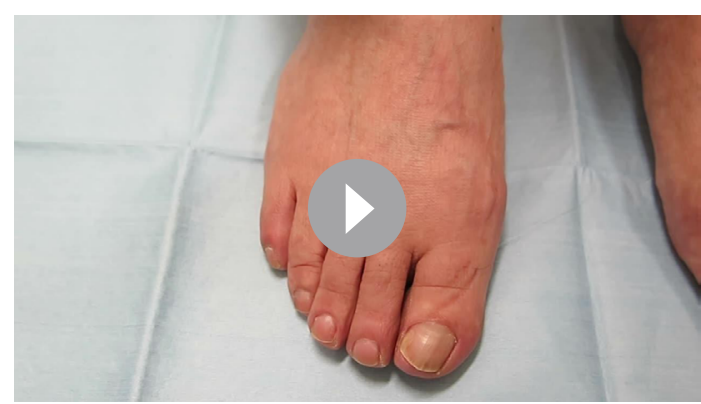

Video 1 The movements of the second and third toes were primarily slow lateral movements (abduction and adduction) irregularly similar to $1-\mathrm{Hz}$ myoclonus.

(11\%), radiculopathy (9\%) or idiopathy (42\%). ${ }^{1}$ The diagnosis of PLMT syndrome is usually based on the unremarkable nature of a patient's neurological symptoms and clinical history. ${ }^{4}$ The differential diagnosis includes restless leg syndrome and akathisia, and thus pramipexole was once tried on this patient. However, restless leg syndrome usually urges to move legs and improves with motion. Akathisia also urges to move whole body.

Response to treatment of PLMT syndrome is unsatisfactory in majority of the patients. ${ }^{2}$ However, it is reported that gabapentin enacarbil, pregabalin or carbamazepine for pain and ropinirole, pramipexole or clonazepam for movements may be effective against PLMT syndrome. ${ }^{1}$ The cause of PLMT syndrome in this case was considered idiopathic and clonazepam partially treated the pain as well as digit movements.

\section{Learning points}

- Involuntary movements can lead to the chief report of pain and dysaesthesia.

- Chronic toe pain accompanied by involuntary movements can be caused by painful legs and moving toes syndrome.

Twitter Kiyoshi Shikino @K

Contributors $\mathrm{HT}, \mathrm{KI}, \mathrm{KS}$ and $\mathrm{MI}$ managed the patient and revised the manuscript. HT and KI wrote the first draft.

Funding The authors have not declared a specific grant for this research from any funding agency in the public, commercial or not-for-profit sectors.

Competing interests None declared.

Patient consent for publication Obtained.

Provenance and peer review Not commissioned; externally peer reviewed.

\section{ORCID iDs}

Hiroki Tamura http://orcid.org/0000-0001-8718-0072

Kosuke Ishizuka http://orcid.org/0000-0003-4313-6592

Kiyoshi Shikino http://orcid.org/0000-0002-3721-3443 
Images in...

\section{REFERENCES}

1 Hassan A, Mateen FJ, Coon EA, et al. Painful legs and moving toes syndrome: a 76-patient case series. Arch Neurol 2012;69:1032-8.

2 Pandey S. Painful leg and moving toes syndrome. Ann Indian Acad Neurol 2015;18:457-8.
3 Oh SM, Yoon WT, Kim JY, et al. Painless legs and moving toes as an initial presentation of ischemic stroke. J Mov Disord 2009;2:40-2.

4 Bosco L, Falzone YM, Butera C, et al. Painful legs and moving toes syndrome: treating movement to treat pain-a case report. J Neuro/ 2020;267:1852-4.

Copyright 2021 BMJ Publishing Group. All rights reserved. For permission to reuse any of this content visit

https://www.bmj.com/company/products-services/rights-and-licensing/permissions/

BMJ Case Report Fellows may re-use this article for personal use and teaching without any further permission.

Become a Fellow of BMJ Case Reports today and you can:

- Submit as many cases as you like

- Enjoy fast sympathetic peer review and rapid publication of accepted articles

- Access all the published articles

- Re-use any of the published material for personal use and teaching without further permission

\section{Customer Service}

If you have any further queries about your subscription, please contact our customer services team on +44 (0) 2071111105 or via email at support@bmj.com.

Visit casereports.bmj.com for more articles like this and to become a Fellow 